\title{
Assessing university's sustainability programs from the perspective of university students: a gap analysis
}

\author{
M. Mujiya Ulkhaq*, Wismar R. Wijayanti, Rahmaningtyas Wiganingrum, Wini R. Dewi, and Fahmi Ardi \\ Department of Industrial Engineering, Faculty of Engineering, Diponegoro University, Semarang - Indonesia
}

\begin{abstract}
The role of universities in promoting sustainability has outstretched over the past decades as a result of abundant declarations related to the need for sustainability in higher education. As consequences, several universities have integrated sustainability into their curricula, research, programs, projects, partnerships, and assessments. However, despite the need for sustainable development in today's highly competitive global network, many university members especially students are still unaware or ignorant of sustainability practices. This research tried to analyse the gap between what the university has done in campaigning for sustainability and what the students have perceived. A case study is conducted in Diponegoro University, Indonesia. Twelve indicators of four variables, i.e., community outreach; sustainability commitment and monitoring; waste and energy; as well as land use and planning are used to accomplish this research. Three hundred and fortyfive students spreading from all faculties participated in the survey. The result shows that an average gap of -0.38 is revealed; indicating that the respondents did not consider a significant impact on the sustainability programs. In addition, more than $50 \%$ of the respondents were not familiar with the sustainability programs. It is suggested that the university has to put more attention in fostering sustainability to its biggest stakeholders.
\end{abstract}

\section{Introduction}

Universities recently become a main player in fostering sustainability through knowledge dissemination. The role has grown progressively across countries since the successful accomplishment of Stockholm Declaration on the Human Environment in 1972 [1] which has been acknowledged as the first reference about sustainability in higher education. Since then, there are numerous conferences, and declarations about the role of higher education in promoting sustainability. Some of them are Belgrade Charter in 1975, Rio de Janeiro's Earth Summit in 1992, Kyoto Declaration in 1993, The Lüneburg Declaration in 2001, Lucerne Declaration in 2007, and Tokyo Declaration in 2009 (see [2] for the detail). In consequence, the concept of sustainability has been integrated into the universities' curricula, researches, operations, partnerships, as well as their assessment and reporting [3 - 6].

These initiatives should be based on the universities", visions along with their managements' concept of sustainability. The rationale is that the concept of sustainability presents diverging interpretations according to the actors that are inferred [7]. Some have a master plan, environmental plan, guidelines, or statement about being sustainable campus [6]; some by signing of national or international declarations [8]; and others create individual institutional policies or framework to achieve campus sustainability, such as ISO 14001 [9 -
11], eco-management and audit scheme (EMAS) [12], green building initiative [13], environmental impact assessment [14], graphical assessment of sustainability in universities (GASU) [15, 16], sustainability tracking, assessment and rating system (STARS) [17, 18], and Alshuwaikat and Abubakar's framework [2, 19, 20].

The sustainability goals, in essence, will not be achieved without cooperation and participation from all stakeholders, i.e., the students, the faculties and staff, funding agencies, as well as the communities [21, 22]. The students, which can be considered as the biggest stakeholders, play a critical role in a bottom-up approach to promote awareness across the institution and urge interactions among various stakeholders [8, 23]. However, despite the tangible and intangible benefits gained from the sustainability practices, many university members, especially the students are still unaware of it [24].

The objective of this research is to analyse the gap between what are the sustainability programs conducted by the universities and what the students have perceived about the programs. Twelve indicators from four variables for the key factors of a sustainable university from the perspective of students by [24] are used, i.e., community outreach, sustainability commitment and monitoring, waste and energy, and land use and planning. A case study to exhibit the applicability of the methods was conducted in Diponegoro University,

\footnotetext{
* Corresponding author: ulkhaq@live.undip.ac.id
} 
which is located in Semarang, Central Java Province, Indonesia.

Table 1 Variables and indicators of assessing universities' sustainability programs

\begin{tabular}{|c|c|c|}
\hline Variable & \multicolumn{2}{|r|}{ Indicators } \\
\hline \multirow{3}{*}{$\begin{array}{l}\text { Communi- } \\
\text { ty outreach }\end{array}$} & $\mathrm{S} 1$ & $\begin{array}{l}\text { The university engages in community } \\
\text { outreach programs that benefit the } \\
\text { local environment }\end{array}$ \\
\hline & $\mathrm{S} 2$ & $\begin{array}{l}\text { The university has created green } \\
\text { community centres to benefit the local } \\
\text { environment }\end{array}$ \\
\hline & $\mathrm{S} 3$ & $\begin{array}{l}\text { The university has created partnerships } \\
\text { with government, non-governmental } \\
\text { organizations, and industry working } \\
\text { toward sustainability }\end{array}$ \\
\hline \multirow{4}{*}{$\begin{array}{l}\text { Sustainabi- } \\
\text { lity com- } \\
\text { mitment \& } \\
\text { monitoring }\end{array}$} & S4 & $\begin{array}{l}\text { The university has created a written } \\
\text { statement of their commitment to sus- } \\
\text { tainability }\end{array}$ \\
\hline & S5 & $\begin{array}{l}\text { Each department within the sus- } \\
\text { tainable university has created its own } \\
\text { written statement of their commit- } \\
\text { ment to sustainability }\end{array}$ \\
\hline & S6 & $\begin{array}{l}\text { Sustainability audits are performed on } \\
\text { the surrounding community }\end{array}$ \\
\hline & S7 & $\begin{array}{l}\text { Regular sustainability audits are } \\
\text { performed on campus }\end{array}$ \\
\hline \multirow{3}{*}{$\begin{array}{l}\text { Waste and } \\
\text { energy }\end{array}$} & S8 & The university reuses campus waste \\
\hline & S9 & $\begin{array}{l}\text { The university uses renewable and safe } \\
\text { energy sources }\end{array}$ \\
\hline & S10 & $\begin{array}{l}\text { The university emphasizes sustain- } \\
\text { ability through support services }\end{array}$ \\
\hline \multirow{2}{*}{$\begin{array}{l}\text { Land use } \\
\text { and plan- } \\
\text { ning }\end{array}$} & S11 & $\begin{array}{l}\text { Campus building planning is a top } \\
\text { priority in university sustainability } \\
\text { issues }\end{array}$ \\
\hline & $\mathrm{S} 12$ & $\begin{array}{l}\text { Campus landuse is a top priority in } \\
\text { university sustainability issues }\end{array}$ \\
\hline
\end{tabular}

\section{Research methods}

Since there are limited researches addressing the issue of sustainability from the perspective of students, we employed the study by [24] to accomplish the objective of this research. There are four variables for the key factors of a sustainable university, i.e., community outreach, sustainability commitment and monitoring, waste and energy, as well as land use and planning. Each variable has their own indicators to assess the universities' sustainability programs.

Community outreach is the activities that engaged by the university outside campus. It consists of three indicators, such as: (i) the university engages in community outreach programs that benefit the local environment, (ii) the university has created green community centres to benefit the local environment, and (iii) the university has created partnerships with government, non-governmental organizations, and industry working toward sustainability. The second variable is sustainability commitment and monitoring. The university as long as each department supposed to create a written statement of its commitment to sustainability, as well as monitoring and audit are performed regularly. It consists of three indicators as well, i.e., (i) the university has created a written statement of their commitment to sustainability; (ii) each department within the sustainable university has created its own written statement of their commitment to sustainability, (iii) sustainability audits are performed on the surrounding community, and (iv) regular sustainability audits are performed on campus. The third one is waste and energy variable. It consists of three indicators, i.e., (i) the university reuses campus waste, (ii) the university uses renewable and safe energy sources, and (iii) the university emphasizes sustainability through support services. The last is land use and planning, which refers to the priority to both build sustainable campus building and use campus land for the sustainability practice. It consists of two indicators, i.e., (i) campus building planning is a top priority in university sustainability issues and (ii) campus landuse is a top priority in university sustainability issues. The total of twelve indicators for each variable are shown in Table 1.

To calculate the gap, there are required two group of respondents. The first group is the university faculties or staff that are associated with the sustainability programs while the second group is the university students. The gap for each indicator is calculated as follows:

$$
\mathrm{Gap}_{i}=S P_{S i}-S P_{F i},
$$

where $S P_{S i}$ is the total score from the perspective of the university students of the sustainability programs for indicator $i$ and $S P_{F i}$ is the total score of the sustainability programs for indicator $i$ from the perspective of the university faculties or staff. The $S P_{S i}$ and $S P_{F i}$ can be calculated as follows:

$S P_{S i}=\frac{\sum_{i=1}^{n_{S}} P_{i j}}{n_{S}}$,

$S P_{F i}=\frac{\sum_{i=1}^{n_{F}} P_{i j}}{n_{F}}$,

where $P_{i j}$ is the score obtained from individual $j$ with respect to the performance of sustainability programs on indicator $i, n_{S}$ is the number of the university students to be sampled, and $n_{F}$ refers to the number of the first group, i.e., the university faculties or staff to be questioned.

\section{Case study: result and discussion}

To exhibit the applicability of the methods, a case study was conducted in the Diponegoro University, Indonesia. As has been previously mentioned, there are two kind of groups to be investigated. The first consists of university faculties or staff that are associated with the university's sustainability programs. It can be the professors or the lecturers that are aware of the programs; or the university staff that monitor or maintain the performance 
of the programs. The second group is the university students that supposed to perceive the university's sustainability programs that have been designed and operated by the university.

Table 2 Respondents' profile of the second group

\begin{tabular}{|c|c|c|}
\hline \multicolumn{2}{|c|}{ Variable } & Percentage \\
\hline \multirow{2}{*}{ Gender } & Male & 29 \\
\hline & Female & 71 \\
\hline \multirow{3}{*}{ Age } & $<20$ years & 37 \\
\hline & $20-23$ years & 62 \\
\hline & $>23$ years & 1 \\
\hline \multirow{3}{*}{$\begin{array}{l}\text { Current level } \\
\text { of the study }\end{array}$} & Diploma & 3 \\
\hline & $\begin{array}{l}\text { Bachelor/under- } \\
\text { graduate }\end{array}$ & 95 \\
\hline & Post-graduate & 2 \\
\hline \multirow{12}{*}{$\begin{array}{l}\text { Faculty/ } \\
\text { School }\end{array}$} & Law & 4 \\
\hline & $\begin{array}{c}\text { Economics and } \\
\text { Business }\end{array}$ & 18 \\
\hline & Engineering & 28 \\
\hline & Medicine & 7 \\
\hline & $\begin{array}{c}\text { Animal and } \\
\text { Agricultural Science }\end{array}$ & 4 \\
\hline & Humanities & 4 \\
\hline & $\begin{array}{c}\text { Social Science and } \\
\text { Political Science }\end{array}$ & 4 \\
\hline & $\begin{array}{l}\text { Science and } \\
\text { Mathematics }\end{array}$ & 10 \\
\hline & Public Health & 9 \\
\hline & $\begin{array}{c}\text { Fisheries and Marine } \\
\text { Science }\end{array}$ & 5 \\
\hline & Psychology & 4 \\
\hline & Vocational School & 3 \\
\hline \multirow{4}{*}{$\begin{array}{l}\text { Period of } \\
\text { the study }\end{array}$} & $<1$ year & 23 \\
\hline & $1-2$ years & 14 \\
\hline & $2-3$ years & 42 \\
\hline & $>3$ years & 21 \\
\hline \multirow{2}{*}{$\begin{array}{l}\text { Have attended } \\
\text { lectures about } \\
\text { environment or } \\
\text { engaged in } \\
\text { social activities? }\end{array}$} & Yes & 78 \\
\hline & No & 22 \\
\hline
\end{tabular}

The potential participants of the second group were first approached and asked if they agreed to participate in the survey. Three hundred and forty five students spreading from all faculties participated in this survey, indicates the diversity for the purpose of the research. Profile of the respondents of the second group is shown in Table 2. The respondents are then questioned about the university's sustainability programs for each indicator. The score " 0 " is given when the programs do not comply at all with the statement (or the indicator); the score " 1 " is given when the statement is more or less fulfilled, but where there is still room for improvement; and finally when the situation in which the statement appears to be completely fulfilled the score or " 2 " is applied. The respondents also are able to answer "do not know" if he or she has no idea about the statement.

The previous procedure was also applied for the first group of the respondents. There are only three respondents participated in the survey, i.e., two respondents are the university staff that monitor the university's environment programs and one is the lecturer of the Department of Environmental Engineering.

Table 3 Case study result

\begin{tabular}{|c|c|c|c|}
\hline Indicators & $\boldsymbol{S P}_{\boldsymbol{S} \boldsymbol{i}}$ & $\boldsymbol{S P}_{\boldsymbol{F} \boldsymbol{i}}$ & $\mathbf{G a p}_{\boldsymbol{i}}$ \\
\hline $\mathrm{S} 1$ & 1.114 & 1.667 & -0.552 \\
\hline S2 & 1.037 & 1.000 & 0.037 \\
\hline S3 & 1.070 & 2.000 & -0.930 \\
\hline S4 & 1.174 & 1.333 & -0.159 \\
\hline S5 & 0.982 & 1.667 & -0.684 \\
\hline S6 & 0.854 & 1.667 & -0.813 \\
\hline S7 & 0.682 & 1.667 & -0.985 \\
\hline S8 & 0.566 & 1.000 & -0.434 \\
\hline S9 & 0.664 & 1.000 & -0.336 \\
\hline S10 & 0.991 & 1.000 & -0.009 \\
\hline S11 & 1.000 & 1.000 & 0 \\
\hline S12 & 1.300 & 1.000 & 0.300 \\
\hline Average & 0.953 & 1.333 & -0.380 \\
\hline
\end{tabular}

The gap for each indicator is then calculated using (1) by calculating (2) and (3) at first. The result is shown in Table 3. Note that we exclude the "do not know" answers coming from the respondents of the first group. Surprisingly, there are 140 "do not know" answers or more than $50 \%$ of the total respondents, indicates that the students are not familiar with the university's sustainability programs. We strongly recommend that the university has to put more attention in promoting its sustainability programs for its biggest stakeholders.

\subsection{Community outreach}

In the community outreach variable, S3 (the university has created partnerships with government, nongovernmental organizations, and industry working toward sustainability) becomes the indicator that has the highest gap, i.e., -0.930 . The students consider that the results gained from partnership created by Diponegoro University cannot be felt properly. However, the university staff claim that the indicator has been fulfilled and realized well. For example, there are several communities that are engaged into the environmental issues. Some of them are "Atmosphere", "Environmental Study Group", “Oxygen 16", "Kesemat", and "Diponegoro Social Care." They have several programs such as green competition, youth dialog, and youth in action by "Atmosphere"; tarakura home method composting by "Environmental Study Group"; campus cleaning and composting by "Oxygen 16"; training for creating biopores; mangrove conservation in Semarang coastal area by "Kesemat"; and garbage bank and plastic and paper campaign by "Diponegoro Social Care" [2].

The University also has established partnership with the French government in mangrove forest conservation. Another partnership that has been created is with the Indonesian government, such as the Ministry of Environment and the Ministry of Forestry. The example 
of partnership with the first party is a preservation program of Rawa Pening, a swamp located near Semarang City, and example partnership with the later party is trees planting program.

However, due to the existence of the gap, the university is suggested to give a promotion or socialization about the partnership with external parties, such as government, non-governmental organizations, as well as industries. In addition, the university is strongly recommended to financially support the local communities and local environment related to sustainability.

It is fortunate that in this variable, there exist one indicator that has positive gap, i.e., S2 (the university has created green community centres to benefit the local environment). It means that the students felt that the green community centres established surrounding Diponegoro University affect the local environment.

\subsection{Sustainability commitment and monitoring}

Indicators from the smallest to the largest gap in sustainability commitment and monitoring variable are S4, S5, S6, and S7, i.e., S4 with -0.159 ; S5 with -0.684 ; S6 with -0.813 ; and S7 with -0.985 . Note that all indicators have negative gaps, indicates that sustainability programs related to university's commitment and monitoring are not felt properly by the students. Therefore, it is strongly recommended that the university does socialization about its commitment to sustainability to the students, even though the university has stated it clearly. Moreover, regular audits and monitoring related to sustainability practices have to be performed transparently.

\subsection{Waste and energy}

Waste or garbage separation as a part of waste management has been completely done by the university. The waste is separated into two categories: organic and inorganic which is thrown away into different trash bin placed in various corners of the university. While organic waste is fully composted, the inorganic waste could be recycled into several recycled products, such as lumber, bottle, rope, garbage cans, scrapers, etc. However, only $25 \%$ to $50 \%$ of wastes that have been recycled. This performance has to be improved significantly in order to gain the number of $90 \%$ to be recycled.

Diponegoro University also has sewage treatment facility that is operated by the Department of Environmental Engineering and the Department of Chemical Engineering. In term of energy utilization, Diponegoro University has replaced conventional energy appliances with energy efficient appliances by $20 \%$ to $40 \%$.

Despite of the sustainability programs abovementioned by the university staff, the students are not familiar with those programs; hence the gap does exist. All indicator have negative gaps: S8 (the university reuses campus waste) is -0.434 ; S9 (the university uses renewable and safe energy sources) is 0.336; S10 (the university emphasizes sustainability through support services) is -0.009 . Therefore, it is recommended to give a socialization to the students and endorse students so that they can enthusiastically participate into those kind of activities.

\subsection{Land use and planning}

It is arguable that some of the buildings in the university have been designed with the concept of energy efficient, such as the building in the Department of Environmental Engineering and in the Department of Industrial Engineering. The rooms are designed so that one big room is partitioned into several small chambers. Only one central air conditioner and one lighting are used for more those partitioned rooms. It could minimize the energy consumption.

The priority to build a building is not based on a sustainability needs. The university faculties stated that the university will build a campus depend on the necessity, such as the number of existing students. The university has a master plan to integrate some classes from different departments into one shared lecturer class. In contrast, the students consider that each department has to have each own campus.

In term of land use, Diponegoro University has a deer park that is built to preserve the deer. In front of deer park, there is an open space for preserving endangered plants. Forest campus and agrotechnopark are new programs which are still in the development stage.

\section{Conclusion}

This study tried to analyse the gap between what the students of the university perceive about sustainability programs and what the performance of the programs. This is motivated by the fact that the students, as the biggest stakeholders of the university are mostly unaware or ignorant of the sustainability programs managed by their university. This is an irony since the sustainability in this today's global competitive network plays an important role.

Four variables to measure university's sustainability practices which consist of total twelve indicators by [24] are used in this research. The university faculties or staff and the students are required to score what they perceive about the performance of the university's sustainability programs. The gap is calculated by subtracting the scores obtained from the university faculties or staff into the scores obtained from the students.

A case study has been conducted in the Diponegoro University, Indonesia, to apply the proposed methods. Three university faculties and three hundred and forty five students participated in the survey. Based on the case study result, from twelve indicators, only one indicator that has positive gap (S12), one has zero gap (S11), and the rest have negative gaps; while the average gap is -0.380 (see Table 3 for the detail). The negative score shows that the sustainability programs are not well 
known by the students. Moreover, more than $50 \%$ of the students are not aware of the university's sustainability programs. It indicates that the university has to put more attention in promoting sustainability programs to its students.

In addition, we strongly recommend that the university has to do socialization to the students about the sustainability programs so that the students can excitedly participated into the programs.

The authors thank to the university faculties, staff, and students that have supported in this research.

\section{References}

1. United Nations, Report of the United Nations Conference on the Human Environment (UN, 1973)

2. M.M. Ulkhaq, P.I. Prayogo, M. Firmansyah, D. Agustina, Int. J. Infor. Educ. Tech 6, 8 (2016)

3. M. Brinkhurst, P. Rose, G. Maurice, J.D. Ackerman, Int. J. Sust. Higher Educ. 12, 4 (2011)

4. W. Calder, R.M. Clugston, Plan. Higher Educ. 31, 3 (2003)

5. A.D. Cortese, Plan. Higher Educ. 31, 3 (2003)

6. L. Velazquez, N. Munguia, A. Platt, J. Taddei, J. Cleaner Prod. 14, 9-11 (2006)

7. N. Lourdel, N. Gondran, V. Laforest, C. Brodhag, Int. J. Sust. Higher Educ. 6, 3 (2005)

8. T.S.A. Wright, Higher Educ. Policy, 15, 2 (2002)
9. R.M. Fisher, Int. J. Sust. Higher Educ. 4, 2 (2003)

10. T.J. Price, Int. J. Sust. Higher Educ. 6, 2 (2005)

11. N.A. Setyorini, M.M. Ulkhaq, D.R. Rasyida, P.R. Setiowati, R. Trianto, Int. J. Adv. Agric. Env. Engg. 3, 2 (2016)

12. B. Delakowitz, A. Hoffmann, Int. J. Sust. Higher Educ. 1, 1 (2000)

13. K.A. Owens, A. Halfacre-Hitchcock, Int. J. Sust. Higher Educ.7, 2 (2006)

14. T.B. Ramosa, T. Cecílio, J.J. de Melo, J. Cleaner Prod. 16, 5 (2008)

15. R. Lozano, J. of Cleaner Prod. 14, 9 (2006)

16. R. Lozano, J. Sust. Higher Educ. 12, 1 (2011)

17. M. Urbanski, W.L. Filho, Env. Dev. Sust. 17, 2 (2015)

18. A. Wigmore, M. Ruiz, Ramon Llull J. App. Ethics 1, $1(2010)$

19. H. M. Alshuwaikat, I. Abubakar, J. Cleaner Prod. 16, 16 (2008)

20. R. de Castro, C.J.C. Jabbour, J. Cleaner Prod. 61 (2013)

21. H. van Weenen, Int. J. Sust. Higher Educ. 1, 1 (2000)

22. T. Wright, Int. J. Sust. Higher Educ. 11, 1 (2010)

23. P. Christensen, M. Thrane, T. Herreborg Jørgensen, M. Lehmann, Int. J. Sust. Higher Educ. 10, 1 (2009)

24. M. Nejati, M. Nejati, J. Cleaner Prod. 48 (2013) 